\title{
Scopolamine effects on intracranial self-stimulation extinction
}

\author{
DOUGLAS A. WELDON and JONATHAN VAUGHAN \\ Hamilton College, Clinton, New York 13323
}

\begin{abstract}
Six rats with lateral hypothalamic electrodes were tested for intracranial self-stimulation after administration of scopolamine hydrobromide, scopolamine methylbromide, or vehicle alone in a repeated measures design. Only scopolamine hydrobromide produced an increase in resistance to extinction of responding. No effects of scopolamine on rates of self-stimulation were observed.
\end{abstract}

There is substantial support for the theory that cholinergic systems in the brain have an inhibitory influence on behavior (Carlton, 1963, 1969). Consistent with this theory, administration of the muscarinic receptor antagonist scopolamine produces an increase in resistance to extinction of operant behavior (Hearst, 1959; Heise, Laughlin, \& Keller, 1970; Herblin, 1968; McKim, 1970; Morley \& Russin, 1978; Stone, 1964). Morley and Russin (1978), however, have shown that scopolamine increases resistance to extinction in tasks involving water but not food motivation. Their results suggest that scopolamine acts upon central thirst mechanisms, and that the generality of the drug effects on extinction might be limited.

Scopolamine administration has also been found to produce an increase in resistance to extinction of intracranial self-stimulation (ICSS) behavior (Hoffman \& Trowill, 1979; Olds, 1970), but the appropriate controls for peripheral anticholinergic effects were not included in these studies. Since scopolamine produces dry mouth and increased heart rate (Innes \& Nickerson, 1975), central cholinergic effects can be concluded only after the demonstration that results from scopolamine do not occur after administration of quaternary ammonium analogues (e.g., methylscopolamine) that do not cross the blood brain barrier easily. Such evidence has been provided for scopolamine effects on resistance to extinction in water-motivated tasks (Morley \& Russin, 1978). The present experiment includes a test for peripheral anticholinergic effects and demonstrates that scopolamineinduced increases in resistance to extinction of ICSS are mediated by the central nervous system.

Scopolamine and atropine have not provided consistent effects on ICSS rates. Scopolamine has been

This research was supported by a faculty grant from Hamilton College to D.A.W. We thank Richard Tipperman, who developed the ICSS laboratory during his year as a Hamilton College Senior Fellow, and Meoh Leng Cheng, who performed the histological work. Requests for reprints may be sent to Douglas A. Weldon, Department of Psychology, Hamilton College, Clinton, New York 13323. reported to cause a decrease in ICSS rates of fast responders (Olds, 1970), but studies that have included very slow responders have reported no effect of the drug (Hoffman \& Trowill, 1979; Newman, 1972). Atropine, which theoretically should have the same effects as scopolamine, was found to have doseand electrode-specific effects by Newman (1972) and facilitatory effects by Vorobyova (1974). The current study investigated the effects of scopolamine on ICSS as a function of current intensity of reinforcement stimulation and extinction.

\section{METHOD}

\section{Animals}

Six male Long Evans rats, bred in the Hamilton College vivarium and derived from animals purchased from Blue Spruce Breeders (NY), were used. The rats were maintained on ad-lib food and water, and room lighting alternated on a 12:12 cycle with lights on at $0600 \mathrm{~h}$. Operations were performed when the animals were 75-80 days of age.

\begin{abstract}
Surgery
Animals were anesthetized with sodium pentobarbital $(40 \mathrm{mg}$ / $\mathrm{kg}$ ) and underwent stereotaxic surgery, including the insertion of three stainless steel screws into the skull and one stainless steel electrode (Plastic Products No. 313) into the lateral hypothalamus/ medial forebrain bundle. The coordinates used for the implantations were AP 4.4, L 1.5, and DV -3.0 with respect to interaural zero, with the incisor bar positioned $5.0 \mathrm{~mm}$ above the earbars. The assembly was held in place by cranioplastic cement, and the wound was sprinkled with sulfathiazole before being closed with interrupted silk sutures.
\end{abstract}

\section{Apparatus}

The three operant chambers were $22.0 \times 21.5 \times 20.5 \mathrm{~cm}$ with two sides constructed of metal and the other two of acrylic. Two $5 \times$ $2.5 \times 2 \mathrm{~cm}$ bars protruded from one wall of each of the chambers. Three shockers provided $60-\mathrm{Hz}$ ac pulses $250 \mathrm{msec}$ in length. Stimulation and data recording were controlled by a PDP-8/e computer.

\section{Procedure}

The experimental testing began 28 days after surgery. Five of the animals had been in other experiments prior to the present study; the sixth animal was experimentally naive. For at least 5 days immediately prior to the experimental manipulations, the animals had experienced daily self-stimulation followed by extinc- 
tion. Thus, each animal's ICSS rates were stable at the time of testing and each animal had experienced extinction previously. Fifteen minutes before testing each day, each rat received an injection of $.5 \mathrm{mg} / \mathrm{kg}$ scopolamine hydrobromide (Sigma Chemical Co.), $1.0 \mathrm{mg} / \mathrm{kg}$ scopolamine hydrobromide, $.5 \mathrm{mg} / \mathrm{kg}$ scopolamine methylbromide, $1.0 \mathrm{mg} / \mathrm{kg}$ scopolamine methylbromide, or vehicle (distilled water) in volumes of $1.0 \mathrm{cc} / \mathrm{kg}$. Each animal received one drug condition on each of the 5 days of the repeated measures design. On every day of testing, each drug condition was received by at least one animal. The five current intensities used in the experiment were $20,15,10,5$, and $0 \mu \mathrm{A}$ above a subthreshold intensity. The animals were run three at a time in daily sessions consisting of one 2 -min period at each of the five intensities in order of descending intensity, followed by $2 \mathrm{~min}$ at the maximum intensity and then by $10 \mathrm{~min}$ of extinction. All animals had a maximum ICSS rate of at least 60 responses $/ \mathrm{min}$, and maximum current intensities used in the testing ranged from 45 to $60 \mu \mathrm{A}$.

\section{Histology}

After the experiment was completed, the animals were deeply anesthetized with sodium pentobarbital and perfused intracardially with saline followed by a $10 \%$ Formalin-saline solution. The brains were extracted, and 40- $\mu \mathrm{m}$ sections were taken and stained with cresyl violet.

\section{RESULTS}

Since the first minute of each ICSS period included the animal's behavioral adjustment to the new intensity, the number of responses in the second minute at each intensity was used in the data analysis. Figure 1 shows the mean self-stimulation rates at the five

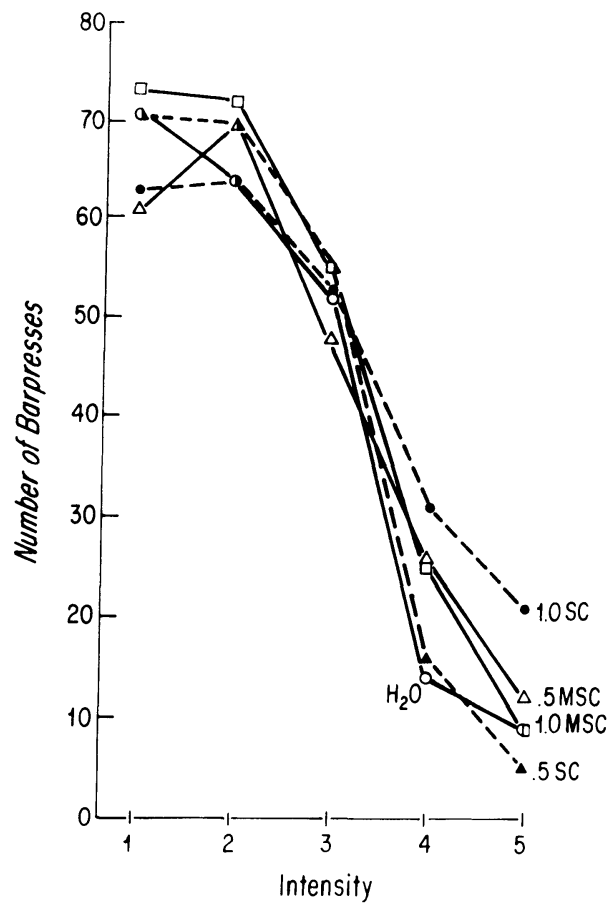

Figure 1. Mean number of barpresses at each of the five current intensities after administration of: vehicle (distilled water), $.5 \mathrm{mg}$ / kg scopolamine hydrobromide (SC), $1.0 \mathrm{mg} / \mathrm{kg}$ scopolamine hydrobromide, $.5 \mathrm{mg} / \mathrm{kg}$ scopolamine methylbromide (MSC), and $1.0 \mathrm{mg} / \mathrm{kg}$ scopolamine methylbromide.

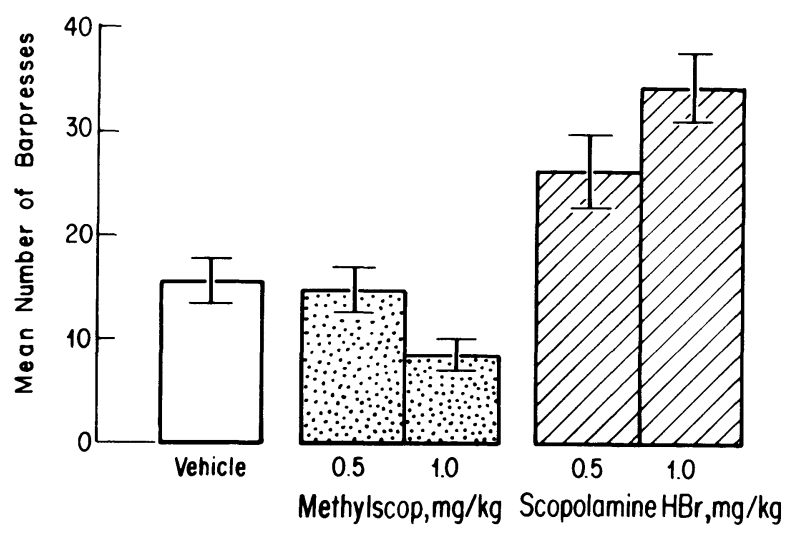

Figure 2. Mean number of barpresses during the 10-min extinction period after administration of: vehicle (distilled water), $.5 \mathrm{mg} / \mathrm{kg}$ scopolamine methylbromide, $1.0 \mathrm{mg} / \mathrm{kg}$ scopolamine methylbromide, $.5 \mathrm{mg} / \mathrm{kg}$ scopolamine hydrobromide, and $1.0 \mathrm{mg} / \mathrm{kg}$ scopolamine hydrobromide. Bars indicate standard errors of the means.

intensities as a function of the five drug conditions. It is clear from the figure that the intensity-response effects did not vary as a function of the drug condition. Analysis of variance found only the effect of intensity to be statistically significant $[F(4,16)=$ $13.01, \mathrm{p}<.0001]$.

Figure 2 shows the mean number of extinction responses as a function of the five drug conditions. Animals pressed more frequently during extinction on those days when scopolamine hydrobromide was administered than when saline or scopolamine methylbromide was administered. The repeated measures analysis of variance indicated a statistically significant effect of drug administered $[F(4,20)=$ $8.24, \mathrm{p}<.0005$ ]. Dunnett's tests showed that only the $1.0-\mathrm{mg} / \mathrm{kg}$ scopolamine hydrobromide condition differed significantly from the control $[\mathrm{t}(5,20)=$ $3.67, \mathrm{p}<.01$ ]. In addition, an analysis for a linear trend was computed for the $0.0,0.5$, and 1.0 scopolamine hydrobromide conditions, and the results indicated a linear relationship $[\mathrm{F}(1,10)=10.44, \mathrm{p}<.01]$. The analysis for departure from linearity, however, did not approach statistical significance.

Histological verification showed the location of the electrodes to be in the vicinity of the lateral hypothalamus/medial forebrain bundle at the level of the posterior hypothalamus (see Figure 3).

\section{DISCUSSION}

The present study demonstrated that scopolamine hydrobromide produces an increased resistance to extinction of ICSS behavior; these results support those of previous investigators (Hoffman \& Trowill, 1979; Olds, 1970). Since the peripheral anticholinergic scopolamine methylbromide did not produce 


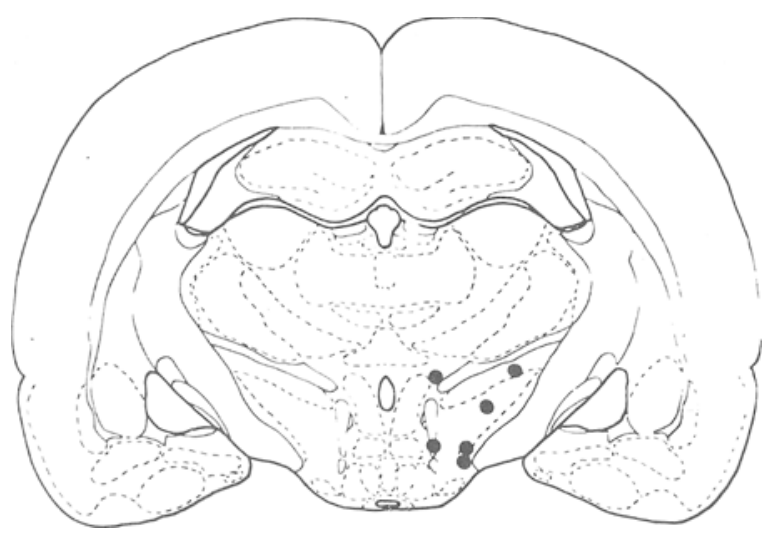

Figure 3. Location of electrodes from the six experimental animals illustrated on a diagram from Pellegrino, Pellegrino, and Cushman (1979).

the same effects as scopolamine hydrobromide, it can now be concluded that the mechanism is a central one. Increases in extinction responding in tasks involving natural rewards have been found after scopolamine administration in some (Hearst, 1959; Heise et al., 1970; Herblin, 1968; McKim, 1970; Morley \& Russin, 1978; Stone, 1964), but not all (McKim, 1980; Morley \& Russin, 1978) experimental situations. Olds (1970) found that fast ICSS responders (>94 responses/min) showed a decrease in barpressing following scopolamine administration. ICSS rates in the present study, however, were not affected by the drugs used. Inspection of individual data records revealed one very fast responder $(>100$ responses/min) that decreased its response rate after scopolamine hydrobromide, but also showed a comparable decrement following scopolamine methylbromide administration. Although strain, dosage, and procedural differences all complicate the interpretation of this discrepancy, it is clear that convincing support for a central effect of scopolamine on ICSS rates has yet to be presented. In contrast, there is substantial evidence that elevation of central acetylcholine levels via inhibition of acetylcholinesterase by physostigmine produces a decrease in ICSS rates (Domino \& Olds, 1968; Jung \& Boyd, 1966; Newman, 1972; Stark \& Boyd, 1963). Similarly, the acetylcholinesterase inhibitor diisopropylfluorophosphate produces an increase in ICSS thresholds (Coons, Schupt, \& Ungerleider, 1976). Muscarinic receptor stimulation with pilocarpine decreases (Newman, 1972), but nicotinic receptor stimulation with nicotine increases ICSS response rates (Newman, 1972; Pradhan \& Bowling, 1971). In view of these reliable effects of cholinergic receptor stimulation, the failure to observe effects of scopolamine on ICSS (Edwards, Wishik, \& Sinnamon, 1979; Hoffman \& Trowill, 1979; the present experiment) appears anomalous.

\section{REFERENCES}

Carlton, P. L. Cholinergic mechanisms in the control of behavior by the brain. Psychological Review, 1963, 70, 19-39.

Carlton, P. L. Brain acetylcholine and inhibition. In J. T. Tapp (Ed.), Reinforcement and behavior. New York: Academic Press, 1969.

Coons, E. E., Schupf, N., \& Ungerleider, L. G. Uses of double-pulse stimulation behaviorally to infer refractoriness, summation, convergence, and transmitter characteristics of hypothalamic reward systems. Journal of Comparative and Physiological Psychology, 1976, 90, 317-342.

Domino, E. F., \& OLds, M. E. Cholinergic inhibition of selfstimulation behavior. Journal of Pharmacology and Experimental Therapeutics, 1968, 164, 202-211.

Edwards, M., Wishik, J., \& Sinnamon, H. M. Catecholaminergic and cholinergic agents and duration regulation of ICSS in the rat. Pharmacology, Biochemistry and Behavior, $1979,10,723-731$.

HEARST, E. Effects of scopolamine on discriminated responding in the rat. Journal of Pharmacology and Experimental Therapeutics, 1959, 126, 349-358.

Heise, G. A., Laughlin, N., \& Keller, C. A behavioral and pharmacological analysis of reinforcement withdrawal. Psychopharmacologia, 1970, 16, 345-368.

Herblin, W. F. Extinction reversal by scopolamine. Psychonomic Science, 1968, 13, 43-44.

Hoffman, D. L., \& Trowill, J. A. Modulation of intracranial reward-punishment interaction by scopolamine. Physiology \& Behavior, 1979, 23, 223-228.

Innes, I. R., \& Nickerson, M. Atropine, scopolamine, and related antimuscarinic drugs. In L. S. Goodman \& A. Gilman (Eds.), The pharmacological basis of therapeutics. New York: Macmillan, 1975.

Jung, O. H., \& Boyd, E. S. Effects of cholinergic drugs on selfstimulation response in rats. American Journal of Physiology, 1966, 210, 432-434.

McKıм, W. A. The effects of scopolamine on the extinction of a continually reinforced response. Psychonomic Science, 1970, 20, 281-282.

McKIM, W. A. The effects of scopolamine on three different types of suppressed behavior of rats. Pharmacology, Biochemistry and Behavior, 1980, 12, 409-412.

Morley, B. J., \& Russin, R. The effects of scopolamine on extinction and spontaneous recovery. Psychopharmacology, 1978, 56, 301-304.

Newman, L. M. Effects of cholinergic agonists and antagonists on self-stimulation behavior in the rat. Journal of Comparative and Physiological Psychology, 1972, 70, 394-413.

OLDS, M. E. Comparative effects of amphetamine, scopolamine, chlordiazepoxide, and diphenylhydantoin on operant and extinction behavior with brain stimulation and reward. Neuropharmacology, 1970, 9, 519-532.

Pellegrino, L. J., Pellegrino, A. S., \& Cushman, A. J. A stereotaxic atlas of the rat brain. New York: Plenum Press, 1979.

Pradhan, S. N., \& Bowling, C. Effects of nicotine on selfstimulation in rats. Journal of Pharmacology and Experimental Therapeutics, 1971, 176, 229-243.

Stark, P., \& Boyd, E. S. Effects of cholinergic drugs on hypothalamic self-stimulation response rates in dogs. American Journal of Physiology, 1963, 205, 745-748.

STONE, G. S. Effects of drugs on nondiscriminated avoidance behavior: I. Individual differences in dose response relationships. Psychopharmacologia, 1964, 6, 245-255.

Vorobyova, T. M. Neuropharmacological analysis of cholinergic mechanism of self-stimulation reactions. Zhurnal Vysshei Nervnoi Deyatel' Nosti, 1974, 24, 172-180. (Abstract) 